\title{
Effect of Extracellular Polymeric Substances on Surface Properties and Attachment Behavior of Acidithiobacillus ferrooxidans
}

\author{
Qian Li ${ }^{1,2,3,+}$, Qianfen Wang ${ }^{1,2,4,+}$, Jianyu Zhu ${ }^{1,2, *}$, Shuang Zhou ${ }^{1,2}$, Min Gan ${ }^{1,2}$, Hao Jiang ${ }^{1}$ \\ and Wolfgang Sand ${ }^{3}$ \\ 1 School of Minerals Processing and Bioengineering, Central South University, Changsha 410083, China; \\ liqian064x@126.com (Q.L.); qianfenwang@126.com (Q.W.); lzj250@163.com (S.Z.); \\ ganmin0803@sina.com (M.G.); jianghao-1@126.com (H.J.) \\ 2 Key Laboratory of Biometallury of Ministry of Education, Central South University, Changsha 410083, China \\ 3 Biofilm Centre, Aquatische Biotechnologie, Universität Duisburg-Essen, Universitätsstraße 5, Essen 45141, \\ Germany; wolfgang.sand@uni-due.de \\ 4 Hualan Biological Bacterin Co., Ltd., Jia No.1, Hualan Ave., Xinxiang 453003, China \\ * Correspondence: zhujy@csu.edu.cn; Tel.: +86-731-8883-6944 \\ + These authors contributed equally to this study.
}

Academic Editor: W. Scott Dunbar

Received: 29 June 2016; Accepted: 22 September 2016; Published: 28 September 2016

\begin{abstract}
Bacterial contact leaching of ores is more effective than non-contact leaching. Adhesion is the first step for leaching bacteria to form a biofilm on a mineral surface. Extracellular polymeric substances (EPS) are pivotal for mediating bacterial adhesion to a substratum. In order to clarify the role of EPS, we measured the adhesion forces between chalcopyrite-, sulfur- or $\mathrm{FeSO}_{4} \cdot 7 \mathrm{H}_{2} \mathrm{O}$-grown cells of Acidithiobacillus ferrooxidans and chalcopyrite by an atomic force microscope (AFM) before and after EPS removal. Surface properties of these cells were assessed by measurements of the contact angle, zeta potential, Fourier transform infrared spectroscopy (FTIR) and acid-base titration. Bacterial attachment to chalcopyrite was monitored for $140 \mathrm{~min}$. The results indicate that the EPS control the surface properties of the cells. In addition, the surface properties are decisive for adhesion. The adhesion forces and the amounts of attached cells decreased dramatically after removing EPS, which was not dependent on the preculture.
\end{abstract}

Keywords: AFM; Acidithiobacillus ferrooxidans; energy source; attachment; EPS

\section{Introduction}

Understanding bacterial attachment to mineral surfaces is important for bioleaching and the control of acid mine drainage [1,2]. Attachment to minerals, the initial step for bacteria to interact with minerals, is dependent on the preculture conditions such as the ionic strength, $\mathrm{pH}$ and energy source. These factors induce bacterial surface hydrophobicity, electrical properties and surface functions $[1,3,4]$, thereby determining how bacteria attach to mineral surfaces.

Bacteria interact with the environment via their surfaces. Thus, extracellular polymeric substances (EPS), which cover bacterial cells, are particularly important for mediating attachment on minerals and, finally, leaching the minerals [5-7]. EPS are mainly composed of carbohydrates, proteins, lipids, uronic acids and extracellular DNA (eDNA). The amount and composition of EPS vary with the energy source. Sulfur- and pyrite-grown cells of A. ferrooxidans secret five or ten times more EPS than iron(II) sulfate-grown cells, respectively. The EPS from iron(II) sulfate- or pyrite-grown cells of A. ferrooxidans are composed of sugars, lipids and small amounts of nitrogen, phosphorus, and free fatty acids, while for sulfur-grown cells an increased content of lipids, free fatty acids and phosphorus 
was detected [5]. The amount of hydrophobic proteins and lipids determines the hydrophobicity of the bacterial surface [8-10]. Bacteria grown on ferrous iron ions contain uronic acids, which complex ferric ions and give the bacterial surface a net positive charge [9-12].

The most widely accepted theories describing bacterial adhesion to minerals are the Derjaguin-Landau-Verwey-Overbeek (DLVO) and the extended DLVO (XDLVO) models [13-16]. The classic DLVO theory accounts for an electrostatic double layer (EL) and Liftshitz-van der Waals (LW) interactions. In the XDLVO theory, the acid-base interactions were added to account for Lewis acid-base interactions. Both theories are used to predict bacteria-mineral adhesion, but fail to accurately describe the bacteria-mineral interactions during adhesion, because they exclude biological interactions such as chemotaxis and steric interactions originating from bacterial exopolymers [13-15,17]. Because of the weakness of these theories, until now studies on the influence of the EPS and the preculture on bacterial adhesion have been scarce.

A direct measurement of the bacterial adhesion force is the best way to study bacteria-mineral interactions. An atomic force microscope (AFM) equipped with a cell probe has developed rapidly to be a useful tool for this purpose [14,15,18,19]. The term 'cell probe' means that cells are immobilized on the tip of an AFM cantilever. With this AFM cantilever, interactions between cells and the substratum can be quantified precisely [20-23]. By using a cell probe in our previous work we measured the adhesion forces between chalcopyrite-, sulfur- or $\mathrm{FeSO}_{4} \cdot 7 \mathrm{H}_{2} \mathrm{O}$-grown cells of $A$. ferrooxidans and chalcopyrite in an iron-free $9 \mathrm{~K}$ medium at $\mathrm{pH} 2$, and found that the preculture showed an impact on bacterial adhesion to chalcopyrite [24]. Diao et al. investigated the effects of the energy source (sulfur and $\mathrm{FeSO}_{4} \cdot 7 \mathrm{H}_{2} \mathrm{O}$ ) on the interaction between cells of $A$. ferrooxidans and silica or pyrite under different salt concentrations [25]. However, the effect of EPS was neither studied nor discussed.

Since no studies seriously took account of EPS when they studied the interaction between leaching bacteria and minerals, in this study we chose $A$. ferrooxidans ATCC $23270^{\mathrm{T}}$ to study the effect of the EPS on the adhesion force and attachment under different culture environments. Firstly, the adhesion forces between $\mathrm{FeSO}_{4} \cdot 7 \mathrm{H}_{2} \mathrm{O}$ - or element sulfur- or chalcopyrite-adapted cells of $A$. ferrooxidans and chalcopyrite were measured. Also the adhesion forces between EPS-deficient cells and chalcopyrite were measured. Furthermore, the physicochemical surface properties of $A$. ferrooxidans were analyzed by contact angle, zeta potential, Fourier transform infrared spectroscopy (FTIR) and acid-base titration experiments before and after EPS removal. Finally, bacterial adhesion to chalcopyrite was recorded over $140 \mathrm{~min}$. The data contribute to an improved understanding of the influence of EPS on bacterial attachment.

\section{Materials and Methods}

\subsection{Strain and Growth Conditions}

A. ferrooxidans ATCC $23270^{\mathrm{T}}$ was purchased from the American Type Culture Collection (ATCC, Rockefeller MD, USA) and was cultured in 9K medium: $\left(\mathrm{NH}_{4}\right)_{2} \mathrm{SO}_{4} 3 \mathrm{~g} / \mathrm{L}, \mathrm{KCl} 0.1 \mathrm{~g} / \mathrm{L}, \mathrm{K}_{2} \mathrm{HPO}_{4} \cdot 3 \mathrm{H}_{2} \mathrm{O}$ $0.5 \mathrm{~g} / \mathrm{L}, \mathrm{MgSO}_{4} \cdot 7 \mathrm{H}_{2} \mathrm{O} 0.5 \mathrm{~g} / \mathrm{L}, \mathrm{Ca}\left(\mathrm{NO}_{3}\right)_{2} 0.01 \mathrm{~g} / \mathrm{L} .4 .47 \% \mathrm{FeSO}_{4} \cdot 7 \mathrm{H}_{2} \mathrm{O}$ or $1 \%$ chalcopyrite or $1 \%$ elemental sulfur were added as energy source. All assays were incubated at $30{ }^{\circ} \mathrm{C}$ and $170 \mathrm{rpm}$. The harvest of bacterial cells was carried out in the mid-exponential phase. The culture was filtered through Whatman 42 filter paper to remove precipitates. The filtrate was then centrifuged at 10,000 rpm for $20 \mathrm{~min}$ at $4{ }^{\circ} \mathrm{C}$. The cell pellet was washed several times with $\mathrm{pH} 2-\mathrm{H}_{2} \mathrm{SO}_{4}$ solution to obtain metabolite-free cells. Ethylenediaminetetraacetic acid (EDTA) was used to remove EPS to obtain EPS-deficient cells.

\subsection{Preparation of Chalcopyrite Coupons}

Chalcopyrite was obtained from Hunan Provincial Museum. The samples were cut into slices with $10 \mathrm{~mm}$ in diameter, $1 \mathrm{~mm}$ in height. After that the slices were polished by using liquid diamond paste of 6,3 , and $0.5 \mu \mathrm{m}$ grain size on a polishing cloth. Then the polished slices were cleaned with 
$70 \%$ ethanol solution and immersed in acetone to prevent oxidation. Some samples were ground into particles with $75 \mu \mathrm{m}$ in diameter.

\subsection{The Operation of the Atomic Force Microscope}

A Nanoscope V Multimode AFM (Digital Instruments) in contact mode was used to record force-distance curves. Differently pre-grown cells of A. ferrooxidans were tested in iron-free $9 \mathrm{~K}$ medium at $\mathrm{pH} 2$ with chalcopyrite coupons. The spring constant of microfabricated $\mathrm{Si}_{3} \mathrm{~N}_{4}$ cantilevers was $0.57 \pm 0.03 \mathrm{nN} / \mathrm{nm}$. Force-distance curves were acquired with a constantly approaching and retracting speed of $500 \mathrm{~nm} / \mathrm{s}$. Further details about cell immobilization and data acquisition have been described previously [18]. After the AFM measurement, all bacteria-coated tips were checked by scanning electron microscopy (SEM) (Figure 1).

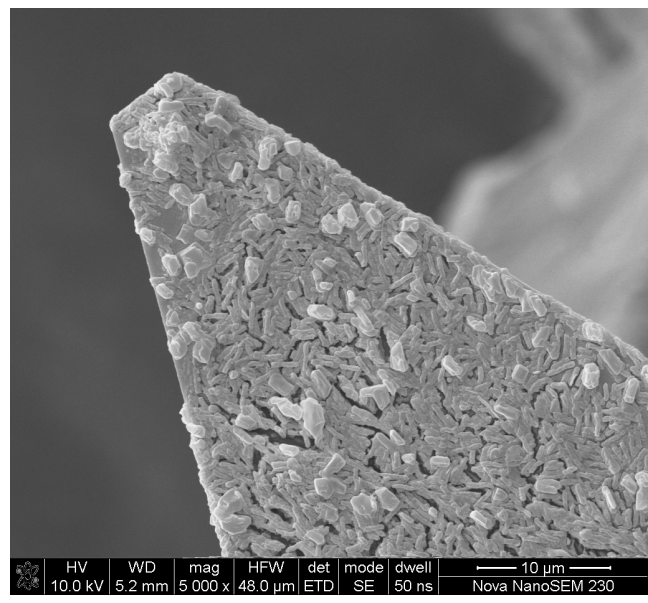

Figure 1. A scanning electron microscopy image of a silicon nitride tip coated with Acidithiobacillus ferrooxidans.

\subsection{Zeta Potential and Contact Angle Measurements}

Cells were harvested and washed as mentioned before and then resuspended in iron-free $9 \mathrm{~K}$ medium at $\mathrm{pH} 2$. After that $5 \mathrm{~mL}$ cell suspension with a cell density of $1 \times 10^{8}$ cells $/ \mathrm{mL}$ was injected into a Zetasizer Nano-ZS MPT-2 (Malvern, UK) to obtain the zeta potential of the cells. Then $1 \%$ freshly ground chalcopyrite grains suspended in iron-free $9 \mathrm{~K}$ medium at $\mathrm{pH} 2$ were used for measuring the zeta potential of the chalcopyrite. All the measurements were done in five times.

Contact angle of water on a chalcopyrite coupon was measured with a telescopic goniometer. Bacterial cell layers were prepared by giving $5 \mathrm{~mL}$ bacteria suspension with a cell density of $1 \times 10^{10}$ cells $/ \mathrm{mL}$ onto porous membranes with a pore size of $0.22 \mu \mathrm{m}$. The contact angle of water on the bacterial cell layer was measured 10 times.

\subsection{FTIR Measurements}

Fourier transformed infrared spectroscopy (FTIR) analyses of native and EPS-deficient cells were performed with a Nicolet Nexus 670 FTIR Spectrometer (Thermo Fisher Scientific, Waltham, MA, USA) at a resolution of $4 \mathrm{~cm}^{-1}$ using a $\mathrm{KBr}$ beamsplitter. For the sample preparation, first obtained the native and the EPS-deficient cells by harvesting and removing the EPS as mentioned before. After freeze drying, the native and EPS-deficient cell samples were directly used for measuring.

\subsection{Acid-Base Titration}

Cells were rinsed several times in $0.01 \mathrm{M} \mathrm{NaCl}$ electrolyte and then suspended in $50 \mathrm{~mL} 0.01 \mathrm{M}$ $\mathrm{NaCl}$ solution $\left(10^{9}\right.$ cells $\left./ \mathrm{mL}\right)$. The suspension was mixed with a magnetic stirrer to ensure homogeneity. 
Acid-base titration was performed following Tourney et al. [26] and carried out using an automatic potentiometric titrator (ZDJ-5) (Shanghai Leici Instrument Factory, Shanghai, China). Titration of the bacterial solution was conducted under a $\mathrm{N}_{2}$ atmosphere at $25 \pm 1{ }^{\circ} \mathrm{C}$. To the suspension were added initially $1 \mathrm{M} \mathrm{HCl}$ solution to adjust the $\mathrm{pH}$ to 2 and then titrated up to $\mathrm{pH} 11$ with $0.01 \mathrm{M}$ $\mathrm{NaOH}$ solution. A stability of $5 \mathrm{mV} / \mathrm{min}$ was attained at each titration step and then the next drop of titrant was added. Blank titration was carried out using $0.01 \mathrm{M} \mathrm{NaCl}$ and each titration was conducted in triplicate.

\subsection{Adhesion Test}

First $50 \mathrm{~mL}$ iron-free 9K medium in $100 \mathrm{~mL}$ Erlenmeyer flasks with $1 \%(w / v)$ chalcopyrite powder were incubated with cell at a density of $1 \times 10^{8}$ cells $/ \mathrm{mL}$ at $170 \mathrm{rpm}$ for $2 \mathrm{~h}$. The number of planktonic cells was then determined by directly counting using a Thoma chamber. The number of attached cells was obtained by subtracting the planktonic cell number from initial one [18]. All tests were repeated three times.

\section{Results and Discussion}

\subsection{Forces between Different Cell Tips and Chalcopyrite before and after EPS Removal}

Figure 2 presents force-distance curves for chalcopyrite-, sulfur- and $\mathrm{FeSO}_{4} \cdot 7 \mathrm{H}_{2} \mathrm{O}$-grown cells of $A$. ferrooxidans immobilized on a cantilever approaching to and retracting from chalcopyrite, respectively. A curvature was observed in the approach curves indicating repulsion (Figure 2a). This may be due to steric or long-distance repulsive forces between the cell probe and chalcopyrite. Similar effects were observed by other researchers $[18,23,27]$. This repulsive force kept increasing until the cell probe contacted the chalcopyrite surface.
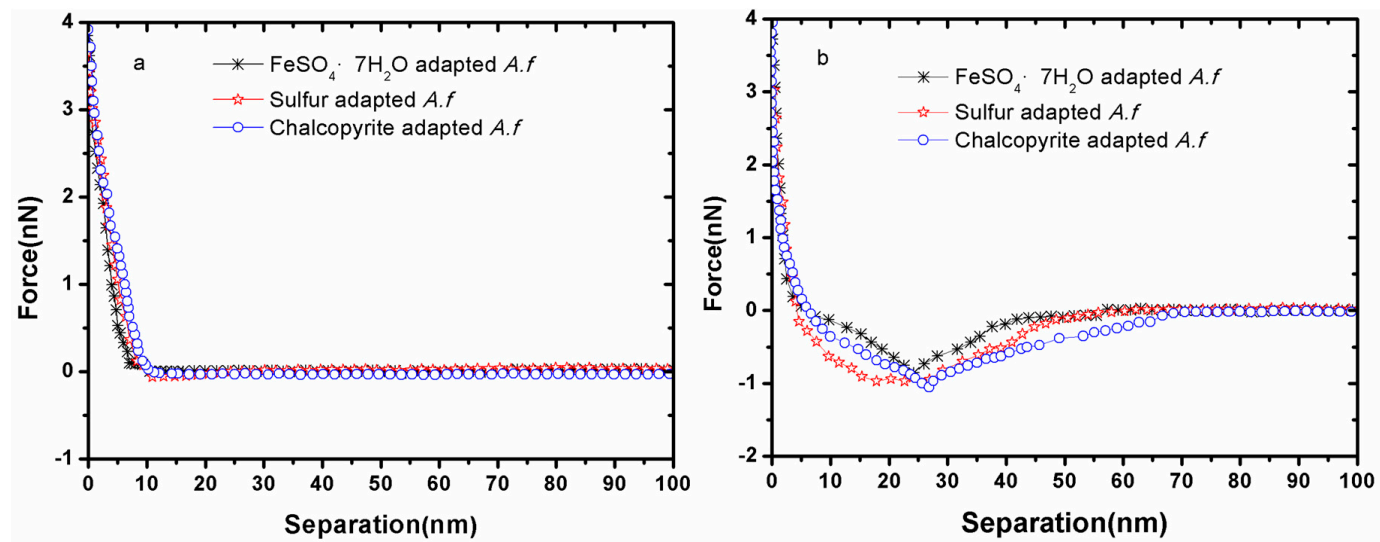

Figure 2. Force-separation curves when different $A$. ferrooxidans (A.f) cell probes were extended to (a) and retracted from $(\mathbf{b})$ chalcopyrite in iron-free $9 \mathrm{~K}$ medium, $\mathrm{pH} 2$.

After contact the cell probe started to retract, but because of adhesion forces the cell probe could not separate from the chalcopyrite surface immediately. The probe kept retracting and, when the deflection force of the cantilever overcame the adhesion force, the cell probe would separate from the chalcopyrite surface. The adhesion peaks from the retraction curves indicate this separation (Figure 2b). At last there was no force that could be detected as the cell probe retracted far away from the chalcopyrite surface. The retraction curve shows complicated dynamic effects of adhesion including bond breaking, intermolecular forces and extension of outer membrane biomolecules [28]. Comparing the values of these force peaks, we can see that chalcopyrite-grown bacteria exhibited the highest adhesion force $(1.0532 \pm 0.1132 \mathrm{nN})$, followed by sulfur-grown bacteria $(0.9677 \pm 0.1070 \mathrm{nN})$ and $\mathrm{FeSO}_{4} \cdot 7 \mathrm{H}_{2} \mathrm{O}$-grown bacteria $(0.8513 \pm 0.0746 \mathrm{nN})$ (Table 1). We have already obtained similar 
results previously, which demonstrates that the experiment is repeatable [24]. Culture history could mainly account for this differentiation, because the energy source affected the cell surface structures and properties. The adhesion force was actually a sum of various biological and physicochemical interactions, which were dependent on cell surface structures and properties.

Table 1. Adhesion forces of different cells of Acidithiobacillus ferrooxidans to chalcopyrite in iron-free 9K medium, pH 2.

\begin{tabular}{cc}
\hline Adhesion Force to Chalcopyrite & nN \\
\hline $\mathrm{FeSO}_{4} \cdot 7 \mathrm{H}_{2} \mathrm{O}$-grown A. ferrooxidans & $0.8513 \pm 0.0746$ \\
EPS-deficient $\mathrm{FeSO}_{4} \cdot 7 \mathrm{H}_{2} \mathrm{O}$-grown A. ferrooxidans & $0.6095 \pm 0.0912$ \\
Sulfur-grown A. ferrooxidans & $0.9677 \pm 0.1070$ \\
EPS-deficient sulfur-grown $A$. ferrooxidans & $0.7828 \pm 0.1260$ \\
Chalcopyrite-grown $A$. ferrooxidans & $1.0532 \pm 0.1132$ \\
EPS-deficient chalcopyrite-grown $A$. ferrooxidans & $0.8335 \pm 0.0841$ \\
\hline
\end{tabular}

Type IV pili of $A$. ferrooxidans play an important role during adhesion, because they contain adhesins [29]. A. ferrooxidans highly expressed pili-associated proteins when high amounts of ferrous ions were available [30]. The elongation of Gram-negative pili was one component of the forces involved in cell adhesion [31]. Accordingly, chalcopyrite- and $\mathrm{FeSO}_{4} \cdot 7 \mathrm{H}_{2} \mathrm{O}$-grown cells should have more pili-associated proteins than sulfur-grown cells. Thus, there were different contributions to the total adhesion force. Some other publications also reported that proteins from the cell outer membrane had a function in the recognition of the substratum, thereby conferring the cells with the ability to adhere to minerals [28,32]. It is most likely that the amount of total protein in the EPS of the three kinds of cells were different, because their total amounts of EPS were different [5].

Hydrophobic forces contribute considerably to microbial adhesion [33]. The energy source can alter bacterial hydrophobicity [5]. Results shown in Table 2 indicate that the hydrophobic forces between chalcopyrite-, sulfur- or $\mathrm{FeSO}_{4} \cdot 7 \mathrm{H}_{2} \mathrm{O}$-grown cells and chalcopyrite were different. Chalcopyrite-grown cells had the strongest hydrophobicity, indicated by the largest contact angle $\left(33.4^{\circ} \pm 1.8^{\circ}\right)$, while $\mathrm{FeSO}_{4} \cdot 7 \mathrm{H}_{2} \mathrm{O}$-grown cells had the lowest one $\left(22.1^{\circ} \pm 1.1^{\circ}\right)$. Besides hydrophobic forces, electrostatic interactions are of importance. The values for the zeta potential in Table 2 demonstrate that in an iron-free $9 \mathrm{~K}$ medium of $\mathrm{pH} 2$, the charge of chalcopyrite was negative and the charge of bacterial cells was positive. Thus, electrostatic interactions between bacteria and chalcopyrite would result in attraction forces. The attractive force between chalcopyrite-grown cells and chalcopyrite was the largest one, whereas that between sulfur-grown cells and chalcopyrite was the lowest one.

Table 2. Contact angle and surface charge of bacteria/chalcopyrite in iron-free 9K medium, pH 2.

\begin{tabular}{ccc}
\hline Sample & Contact Angle $\left(^{\circ}\right)$ & Zeta Potential $(\mathbf{m V})$ \\
\hline $\mathrm{FeSO}_{4} \cdot 7 \mathrm{H}_{2} \mathrm{O}^{-g r o w n}$ A. ferrooxidans & $22.1 \pm 1.1$ & $4.22 \pm 0.52$ \\
EPS-deficient $\mathrm{FeSO}_{4} \cdot 7 \mathrm{H}_{2} \mathrm{O}$-grown A. ferrooxidans & $17.6 \pm 1.6$ & $0.32 \pm 0.21$ \\
Sulfur-grown A. ferrooxidans & $28.3 \pm 1.3$ & $3.33 \pm 0.62$ \\
EPS-deficient sulfur-grown A. ferrooxidans & $19.1 \pm 1.8$ & $-0.03 \pm 0.43$ \\
Chalcopyrite-grown A. ferrooxidans & $33.4 \pm 1.8$ & $4.63 \pm 0.48$ \\
EPS-deficient chalcopyrite-grown A. ferrooxidans & $20.3 \pm 1.2$ & $0.46 \pm 0.35$ \\
Chalcopyrite & $60.7 \pm 6.2$ & $-52.6 \pm 4.86$ \\
\hline
\end{tabular}

Figure 3 shows force-distance curves for cantilevers coated with EPS-deficient chalcopyrite-, sulfur- or $\mathrm{FeSO}_{4} \cdot 7 \mathrm{H}_{2} \mathrm{O}$-grown cells of $A$. ferrooxidans approached to and retracted from chalcopyrite, respectively. The results clearly show that the EPS were pivotal for the adhesion. Compared with the values for untreated bacteria, all approach curves indicate a decreased distance of repulsion (Figure 3a), while all the retraction curves illustrate that the distance of the "separation" event as well as the magnitude of the adhesion force were reduced (Figure $3 b$ ). The steric effect of the EPS can be 
responsible for this change. EPS effectively increased the radius of the cellular action, which then contributed positively to the interactions between the bacteria and minerals $[1,34]$. The reduced values for the contact angle and the zeta potential demonstrate that both hydrophobicity and electrostatic forces were reduced for EPS-deficient cells (Table 2). It is noticeable that after EPS removal, the surface charge properties of sulfur-grown cells changed from positive to negative values. In addition, the cellular appendages might have been destroyed by the EPS removal. Thus, we can conclude that EPS possibly inducing cellular appendages govern the cellular surface properties and are responsible for cell adhesion.
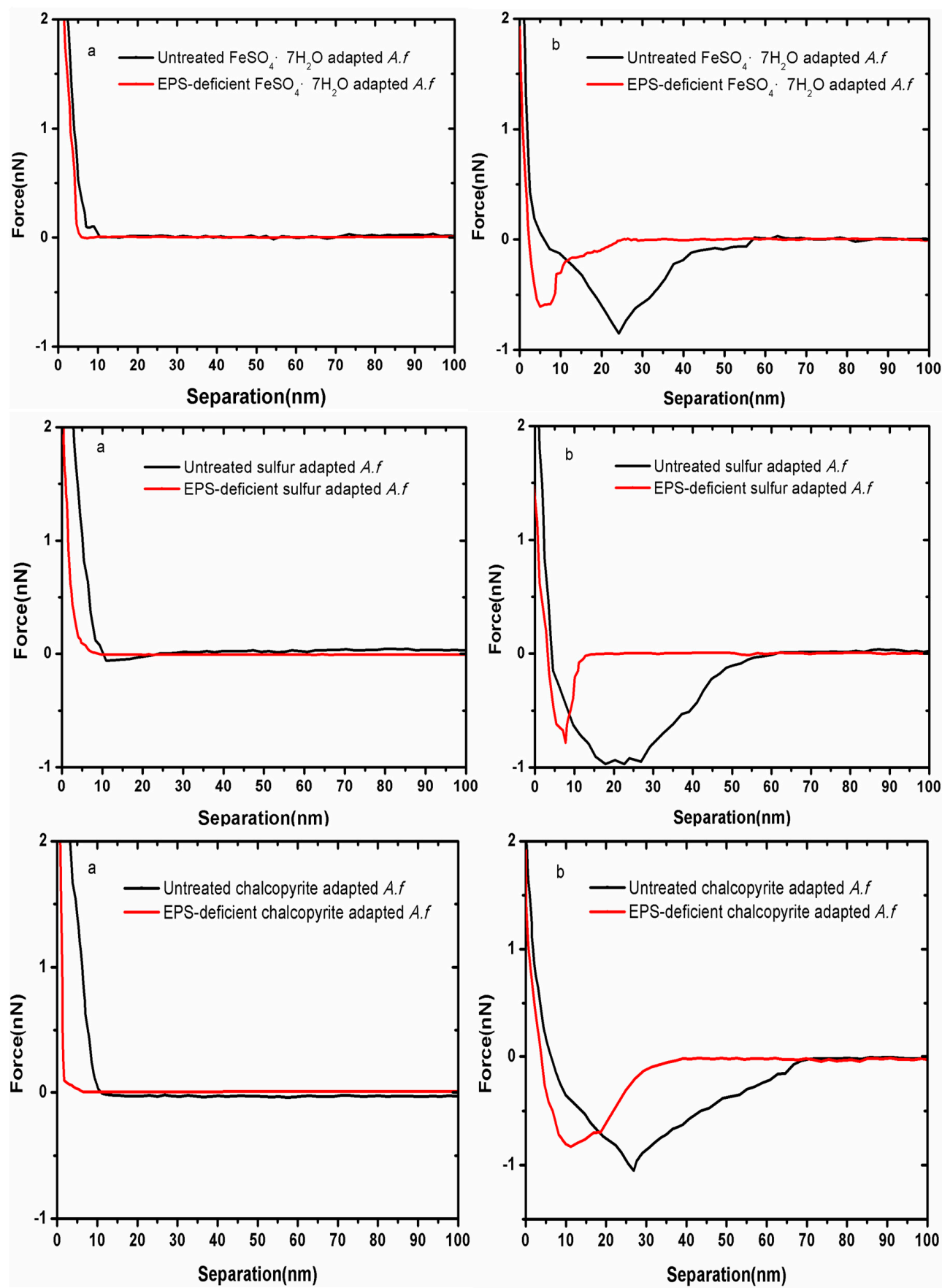

Figure 3. Effect of EPS removal on the approach (a) and the retraction (b) curves between different cells of A. ferrooxidans and chalcopyrite. 


\subsection{Fourier Transform Infrared (FTIR) Spectroscopy}

FTIR spectra of cellular surfaces for chalcopyrite-, sulfur- or $\mathrm{FeSO}_{4} \cdot 7 \mathrm{H}_{2} \mathrm{O}$-grown cells of A. ferrooxidans as well as EPS-deficient cells are presented in Figure 4. The spectra have quite similar bands and represent vibrations of single bonds or functional groups resulting from carbohydrates, proteins and lipids [35]. The band at $2926 \mathrm{~cm}^{-1}$ was characterized as an asymmetric $-\mathrm{CH}_{2}$ stretching from fatty acids. Very intensive bands between 1750 and $1620 \mathrm{~cm}^{-1}$ indicated the $-\mathrm{C}=\mathrm{O}$ group from membrane lipids and fatty acids. Bands at $1661 \mathrm{~cm}^{-1}$ and between 1550 to $1515 \mathrm{~cm}^{-1}$ were assigned to the $-\mathrm{NH}_{2}$ bending of the primary amide group and the $-\mathrm{NH}$ bending of the secondary amide group $(-\mathrm{CONH})$, respectively. Bands at 1445 and $1399 \mathrm{~cm}^{-1}$ were assigned to the bending of the $-\mathrm{CH}_{3}$ and $-\mathrm{CH}_{2}$ groups from proteins. Bands at 1240,1155 and $1082 \mathrm{~cm}^{-1}$ were due to $-\mathrm{P}=\mathrm{O}$ stretching from phosphate, $-\mathrm{CH}_{3}$ wagging and $-\mathrm{CH}_{2}$ twisting modes from carbohydrates, respectively. After EPS removal, the intensity of all bands became much weaker than before. This indicated a positive correlation between the band intensity and the EPS amount. The intensity of the bands from chalcopyrite- and sulfur-grown cells of $A$. ferrooxidans is stronger than that of $\mathrm{FeSO}_{4} \cdot 7 \mathrm{H}_{2} \mathrm{O}$-grown ones. Gehrke et al. [5] also reported that $A$. ferrooxidans produced more EPS when they were grown on solid substrata such as pyrite or sulfur compared with cells grown on soluble substrata such as ferrous iron. Thus, the type of surface functional groups was quite similar for differently pregrown cells; however, the amount of the functional groups differed according to the substrata.
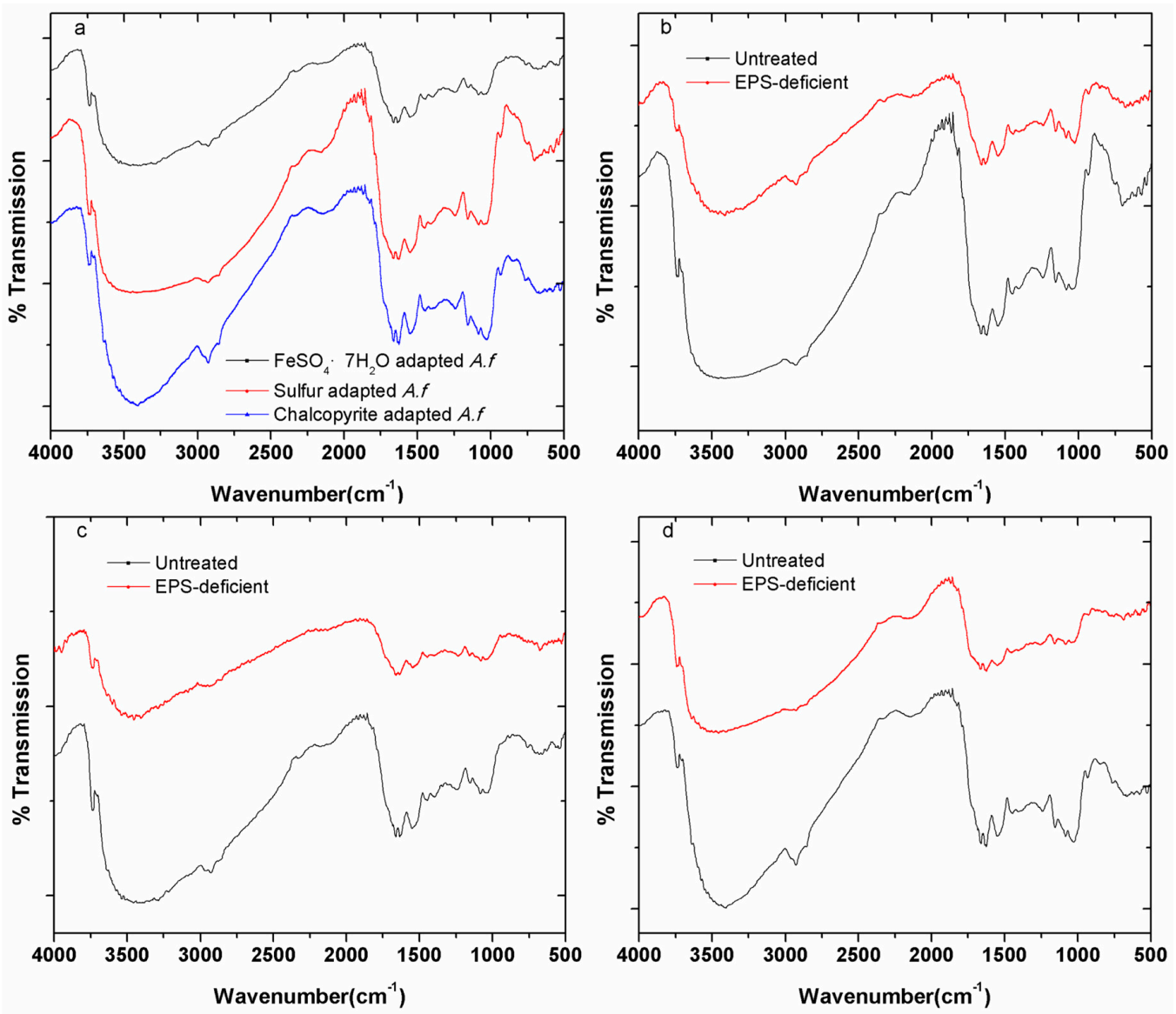

Figure 4. FTIR spectra of cells of $A$. ferrooxidans grown on different energy sources (a); untreated and EPS-deficient $\mathrm{FeSO}_{4} \cdot 7 \mathrm{H}_{2} \mathrm{O}$-grown $A$. ferrooxidans (b); untreated and EPS-deficient sulfur-grown A. ferrooxidans (c); untreated and EPS-deficient chalcopyrite-grown A. ferrooxidans (d).

Functional groups $\left(\mathrm{R}-\mathrm{NH}_{2}, \mathrm{R}-\mathrm{COOH}, \mathrm{R}-\mathrm{OH}, \mathrm{R}-\mathrm{PO}_{2}\right)$ contribute to the surface potential. Their ability to complex metal ions was reported before [36,37]. Our data confirm this. For example, 
iron ions were complexed by uronic acids in the EPS, causing them to be positively charged [38]. Sulfur-grown cells had only a few ferric iron ions complexed because of their limited amount of uronic acids in the EPS [5], but their surface charge was still positive. Metal ions from basic salt medium, complexed by functional groups, may be responsible for the positive charge. Furthermore, why, after EPS removal, sulfur-grown cells exhibited a negative charge is clear: EDTA as a metal chelator removed the metal ions from these functional groups, rendering the cells negatively charged.

\subsection{Acid-Base Titration}

Figure 5 shows titration curves for different cells of $A$. ferrooxidans in $0.01 \mathrm{M} \mathrm{NaCl}$ solution. As the amount of the added base increased, the $\mathrm{pH}$ of the cell suspension increased. However, before the $\mathrm{pH}$ ascended dramatically, the $\mathrm{pH}$ stabilized within a certain range, which illustrates that the cells of A. ferrooxidans empowered $\mathrm{NaCl}$ solution buffering capacity. The deprotonation of functional groups on the cell surface increased the solution buffering capacity to the added base. The functional groups included carboxylic, phosphoric, phosphodiester, amino and hydroxyl groups [39]. Thus, the buffering capacity of the cell suspension indicated the amounts of functional groups on the cell surface. Figure 5a clearly shows that chalcopyrite-grown cell suspension could buffer $16 \mathrm{~mL}$ base, while $14 \mathrm{~mL}$ and $13 \mathrm{~mL}$ base were buffered by sulfur- and $\mathrm{FeSO}_{4} \cdot 7 \mathrm{H}_{2} \mathrm{O}$-grown cell suspension, respectively. In another word, the highest numbers of functional groups were found on the chalcopyrite-grown cell surface compared to the other two. Our FTIR results confirmed the existence of these functional groups. From the spectra we deduce that chalcopyrite-grown cells had the highest numbers of functional groups on their surface because of the strongest bands. $\mathrm{FeSO}_{4} \cdot 7 \mathrm{H}_{2} \mathrm{O}$-grown cells had the weakest bands, and accordingly, the lowest buffering capacity. After removal of the EPS, the bands were less intensive. As a consequence, the buffering capacity of all bacterial solutions decreased. It suggests that the buffering capacity is related to the amounts of EPS.
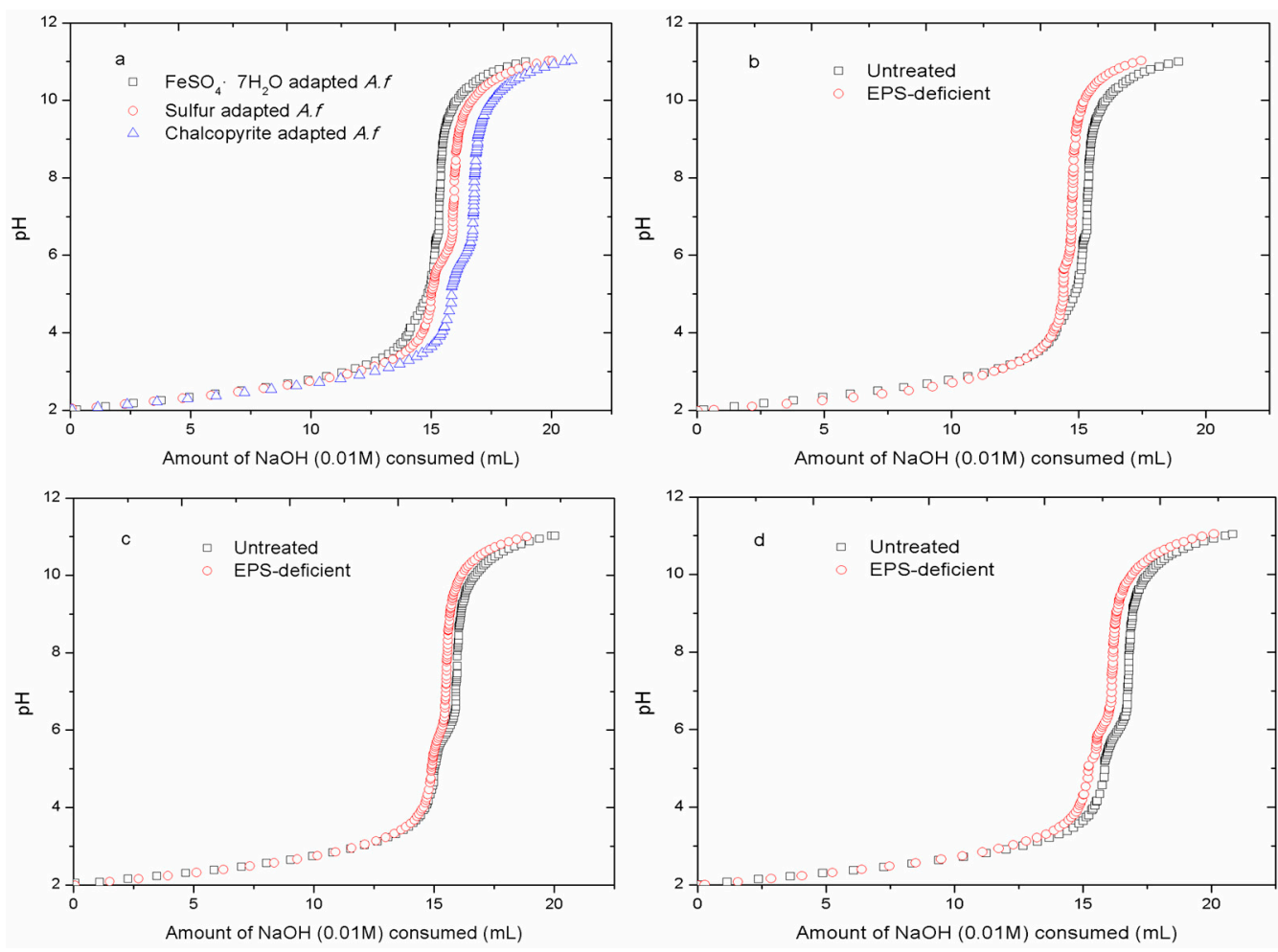

Figure 5. Acid-base titration data from A. ferrooxidans grown on different energy sources (a); untreated and EPS-deficient $\mathrm{FeSO}_{4} \cdot 7 \mathrm{H}_{2} \mathrm{O}$-grown $A$. ferrooxidans (b); untreated and EPS-deficient sulfur-grown A. ferrooxidans (c); untreated and EPS-deficient chalcopyrite-grown A. ferrooxidans (d). 


\subsection{Adhesion Curves}

Figure 6 shows the attachment behavior of differently pre-grown cells of $A$. ferrooxidans and of their EPS-deficient cells to chalcopyrite. A positive correlation was found between the adhesion force and the amount of attached cells. Around $65 \%$ of chalcopyrite-grown cells attached to chalcopyrite, while for sulfur- and $\mathrm{FeSO}_{4} \cdot 7 \mathrm{H}_{2} \mathrm{O}$-grown cells only $60 \%$ or $55 \%$ attached, respectively. The ability of adhesion was reduced after the removal of EPS. For sulfur- and $\mathrm{FeSO}_{4} \cdot 7 \mathrm{H}_{2} \mathrm{O}$-grown cells, the number of attached cells decreased approximately by $25 \%$, and by $15 \%$ for chalcopyrite-grown cells. Thus, EPS were mainly responsible for cell attachment.

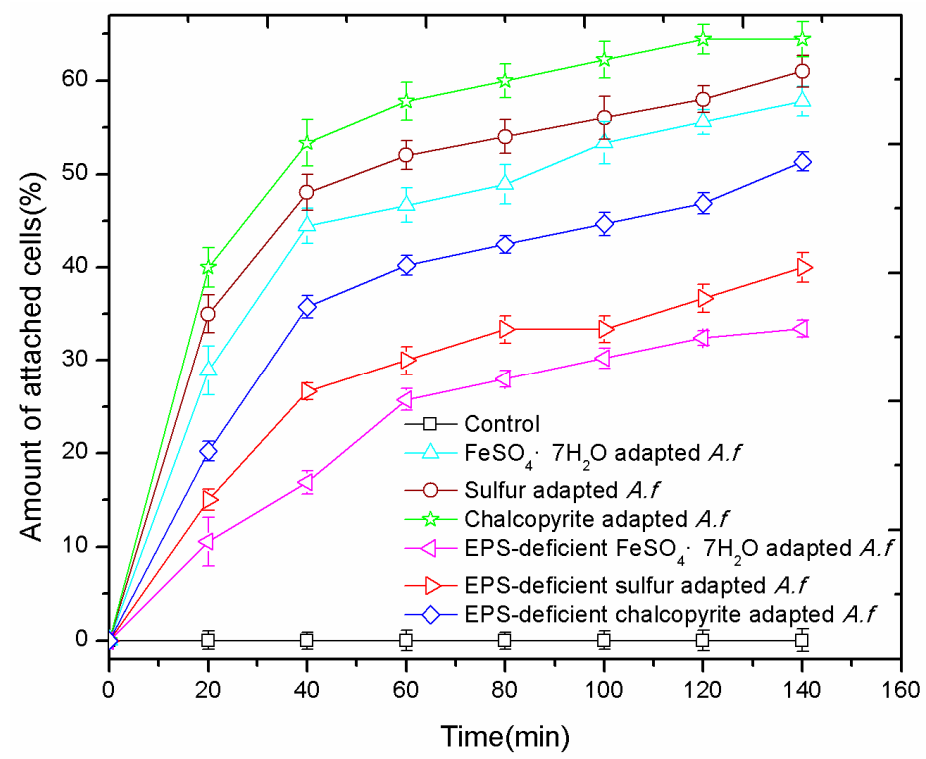

Figure 6. Attachment of different cells of A. ferrooxidans to chalcopyrite. No chalcopyrite was added in the group of control.

\section{Conclusions}

Bacterial adhesion to minerals is a complex process and it is mediated by cell surface properties via EPS. The environment, such as culturing conditions, affects the cell surface properties; thus, the different precultures exhibit varied adhesion forces to the same substratum. Since EPS play an important role during bacterial adhesion to a substratum, the effects from EPS have to be taken account when studying the bacteria-substrata interactions.

Acknowledgments: This work was supported by the National Natural Science Foundation of China (No. 51174239, 30700008, 50974134), the National Basic Research Program of China (No. 2010CB630905) and Fundamental Research Funds for the Central Universities of Central South University. Qian Li gratefully acknowledges the China Scholarship Council (CSC) for financial funding.

Author Contributions: Jianyu Zhu and Wolfgang Sand conceived and designed the experiments; Qianfen Wang, Shuang Zhou, Min Gan and Hao Jiang performed the experiments; Qian Li and Qianfen Wang analyzed all the data; Qian Li and Qianfen Wang wrote the paper. All authors read and approved the manuscript.

Conflicts of Interest: The authors declare no conflict of interest.

\section{References}

1. Africa, C.J.; van Hille, R.P.; Harrison, S.T. Attachment of Acidithiobacillus ferrooxidans and Leptospirillum ferriphilum cultured under varying conditions to pyrite, chalcopyrite, low-grade ore and quartz in a packed column reactor. Appl. Microbiol. Biotechnol. 2013, 97, 1317-1324. [CrossRef] [PubMed]

2. Tan, S.N.; Chen, M. Early stage adsorption behaviour of Acidithiobacillus ferrooxidans on minerals I: An experimental approach. Hydrometallurgy 2012, 119-120, 87-94. [CrossRef] 
3. Diao, M.; Nguyen, T.A.H.; Taran, E.; Mahler, S.; Nguyen, A.V. Differences in adhesion of A. thiooxidans and A. ferrooxidans on chalcopyrite as revealed by atomic force microscopy with bacterial probes. Miner. Eng. 2014, 61, 9-15. [CrossRef]

4. Yee, N.; Fein, J.B.; Daughney, C.J. Experimental study of the $\mathrm{pH}$, ionic strength, and reversibility behavior of bacteria-mineral adsorption. Geochim. Cosmochim. Acta 2000, 64, 609-617. [CrossRef]

5. Gehrke, T.; Telegdi, J.; Thierry, D.; Sand, W. Importance of extracellular polymeric substances from Thiobacillus ferrooxidans for bioleaching. Appl. Environ. Microbiol. 1998, 64, 2743-2747. [PubMed]

6. Usher, K.M.; Shaw, J.A.; Kaksonen, A.H.; Saunders, M. Elemental analysis of extracellular polymeric substances and granules in chalcopyrite bioleaching microbes. Hydrometallurgy 2010, 104, 376-381. [CrossRef]

7. Wei, X.; Fang, L.C.; Cai, P.; Huang, Q.Y.; Chen, H.; Liang, W.; Rong, X.M. Influence of extracellular polymeric substances (EPS) on Cd adsorption by bacteria. Environ. Pollut. 2011, 159, 1369-1374. [CrossRef] [PubMed]

8. Devasia, P.; Natarajan, K.A.; Sathyanarayana, D.N.; Rao, G.R. Surface chemistry of Thiobacillus ferrooxidans relevant to adhesion on mineral surfaces. Appl. Environ. Microbiol. 1993, 59, 4051-4055. [PubMed]

9. Sharma, P. Surface characterization of Acidithiobacillus ferrooxidans cells grown under different conditions. Hydrometallurgy 2003, 71, 285-292. [CrossRef]

10. Xia, L.X.; Liu, X.X.; Zeng, J.; Yin, C.; Gao, J.; Liu, J.S.; Qu, G.Z. Mechanism of enhanced bioleaching efficiency of Acidithiobacillus ferrooxidans after adaptation with chalcopyrite. Hydrometallurgy 2008, 92, 95-101. [CrossRef]

11. Kinzler, K.; Gehrke, T.; Telegdi, J.; Sand, W. Bioleaching-A result of interfacial processes caused by extracellular polymeric substances (EPS). Hydrometallurgy 2003, 71, 83-88. [CrossRef]

12. Zeng, W.M.; Qiu, G.Z.; Zhou, H.B.; Liu, X.D.; Chen, M.; Chao, W.L.; Zhang, C.G.; Peng, J.H. Characterization of extracellular polymeric substances extracted during the bioleaching of chalcopyrite concentrate. Hydrometallurgy 2010, 100, 177-180. [CrossRef]

13. Sharma, P.K.; Rao, K.H. Adhesion of Paenibacillus polymyxa on chalcopyrite and pyrite: Surface thermodynamics and extended DLVO theory. Colloids Surf. B Biointerfaces 2003, 29, 21-38. [CrossRef]

14. Thwala, J.M.; Li, M.; Wong, M.C.; Kang, S.; Hoek, E.M.; Mamba, B.B. Bacteria-polymeric membrane interactions: Atomic force microscopy and XDLVO predictions. Langmuir 2013, 29, 13773-13782. [CrossRef] [PubMed]

15. Harimawan, A.; Zhong, S.P.; Lim, C.T.; Ting, Y.P. Adhesion of B. subtilis spores and vegetative cells onto stainless steel-DLVO theories and AFM spectroscopy. J. Colloid Interface Sci. 2013, 405, 233-241. [CrossRef] [PubMed]

16. Farahat, M.; Hirajima, T.; Sasaki, K. Adhesion of Ferroplasma acidiphilum onto pyrite calculated from the extended DLVO theory using the van Oss-Good-Chaudhury approach. J. Colloid Interface Sci. 2010, 349, 594-601. [CrossRef] [PubMed]

17. Rijnaarts, H.H.M.; Norde, W.; Lyklema, J.; Zehnder, A.J.B. DLVO and steric contributions to bacterial deposition in media of different ionic strengths. Colloids Surf. B Biointerfaces 1999, 14, 179-195. [CrossRef]

18. Zhu, J.; Li, Q.; Jiao, W.; Jiang, H.; Sand, W.; Xia, J.; Liu, X.; Qin, W.; Qiu, G.; Hu, Y.; et al. Adhesion forces between cells of Acidithiobacillus ferrooxidans, Acidithiobacillus thiooxidans or Leptospirillum ferrooxidans and chalcopyrite. Colloids Surf. B Biointerfaces 2012, 94, 95-100. [CrossRef] [PubMed]

19. Bowen, W.R.; Lovitt, R.W.; Wright, C.J. Direct quantification of Aspergillus niger spore adhesion to mica in air using an atomic force microscope. Colloids Surf. A Physicochem. Eng. Asp. 2000, 173, 205-210. [CrossRef]

20. Boonaert, C.J.P.; Dufrene, Y.F.; Derclaye, S.R.; Rouxhet, P.G. Adhesion of Lactococcus lactis to model substrata: Direct study of the interface. Colloids Surf. B Biointerfaces 2001, 22, 171-182. [CrossRef]

21. Chandraprabha, M.N.; Somasundaran, P.; Natarajan, K.A. Modeling and analysis of nanoscale interaction forces between Acidithiobacillus ferrooxidans and AFM tip. Colloids Surf. B Biointerfaces 2010, 75, 310-318. [CrossRef] [PubMed]

22. Senechal, A.; Carrigan, S.D.; Tabrizian, M. Probing surface adhesion forces of Enterococcus faecalis to medical-grade polymers using atomic force microscopy. Langmuir 2004, 20, 4172-4177. [CrossRef] [PubMed]

23. Sheng, X.; Ting, Y.P.; Pehkonen, S.O. Force measurements of bacterial adhesion on metals using a cell probe atomic force microscope. J. Colloid Interface Sci. 2007, 310, 661-669. [CrossRef] [PubMed]

24. Zhu, J.; Wang, Q.; Zhou, S.; Li, Q.; Gan, M.; Jiang, H.; Qin, W.; Liu, X.; Hu, Y.; Qiu, G. Insights into the relation between adhesion force and chalcopyrite-bioleaching by Acidithiobacillus ferrooxidans. Colloids Surf. B Biointerfaces 2015, 126, 351-357. [CrossRef] [PubMed] 
25. Diao, M.; Nguyen, T.A.; Taran, E.; Mahler, S.M.; Nguyen, A.V. Effect of energy source, salt concentration and loading force on colloidal interactions between Acidithiobacillus ferrooxidans cells and mineral surfaces. Colloids Surf. B Biointerfaces 2015, 132, 271-280. [CrossRef] [PubMed]

26. Tourney, J.; Ngwenya, B.T.; Mosselmans, J.W.F.; Tetley, L.; Cowie, G.L. The effect of extracellular polymers (EPS) on the proton adsorption characteristics of the thermophile Bacillus licheniformis S-86. Chem. Geol. 2008, 247, 1-15. [CrossRef]

27. Liu, Z.D.; Li, J.Y.; Jiang, J.; Hong, Z.N.; Xu, R.K. Adhesion of Escherichia coli to nano-Fe/Al oxides and its effect on the surface chemical properties of Fe/Al oxides. Colloids Surf. B Biointerfaces 2013, 110, $289-295$. [CrossRef] [PubMed]

28. Lower, S.K.; Hochella, M.F.; Beveridge, T.J. Bacterial recognition of mineral surfaces: Nanoscale interactions between Shewanella and $\alpha$-FeOOH. Science 2001, 292, 1360-1363. [CrossRef] [PubMed]

29. Li, Y.Q.; Wan, D.S.; Huang, S.S.; Leng, F.F.; Yan, L.; Ni, Y.Q.; Li, H.Y. Type IV pili of Acidithiobacillus ferrooxidans are necessary for sliding, twitching motility, and adherence. Curr. Microbiol. 2010, 60, 17-24. [CrossRef] [PubMed]

30. Tu, B.; Wang, F.; Li, J.; Sha, J.; Lu, X.; Han, X. Analysis of genes and proteins in Acidithiobacillus ferrooxidans during growth and attachment on pyrite under different conditions. Geomicrobiol. J. 2013, 30, 255-267. [CrossRef]

31. Dufrene, Y.F. Sticky microbes: Forces in microbial cell adhesion. Trends Microbiol. 2015, 23, $376-382$. [CrossRef] [PubMed]

32. Brown, S. Engineered iron oxide-adhesion mutants of the Escherichia coli phage lambda receptor. Proc. Natl. Acad. Sci. USA 1992, 89, 8651-8655. [CrossRef] [PubMed]

33. Doyle, R.J. Contribution of the hydrophobic effect to microbial infection. Microbes Infect. 2000, 2, 391-400. [CrossRef]

34. Rohwerder, T.; Gehrke, T.; Kinzler, K.; Sand, W. Bioleaching review (part A): Progress in bioleaching: Fundamentals and mechanisms of bacterial metal sulfide oxidation. Appl. Microbiol. Biotechnol. 2003, 63, 239-248. [CrossRef] [PubMed]

35. Schmitt, J.; Flemming, H.C. FTIR-spectroscopy in microbial and material analysis. Int. Biodeterior. Biodegrad. 1998, 41, 1-11. [CrossRef]

36. Dittrich, M.; Sibler, S. Cell surface groups of two picocyanobacteria strains studied by zeta potential investigations, potentiometric titration, and infrared spectroscopy. J. Colloid Interface Sci. 2005, 286, 487-495. [CrossRef] [PubMed]

37. Fang, L.; Huang, Q.; Wei, X.; Liang, W.; Rong, X.; Chen, W.; Cai, P. Microcalorimetric and potentiometric titration studies on the adsorption of copper by extracellular polymeric substances (EPS), minerals and their composites. Bioresour. Technol. 2010, 101, 5774-5779. [CrossRef] [PubMed]

38. Vera, M.; Schippers, A.; Sand, W. Progress in bioleaching: Fundamentals and mechanisms of bacterial metal sulfide oxidation-Part A. Appl. Microbiol. Biotechnol. 2013, 97, 7529-7541. [CrossRef] [PubMed]

39. Cox, J.S.; Smith, D.S.; Warren, L.A.; Ferris, F.G. Characterizing heterogeneous bacterial surface functional groups using discrete affinity spectra for proton binding. Environ. Sci. Technol. Lett. 1999, 33, 4514-4521. [CrossRef]

(C) 2016 by the authors; licensee MDPI, Basel, Switzerland. This article is an open access article distributed under the terms and conditions of the Creative Commons Attribution (CC-BY) license (http://creativecommons.org/licenses/by/4.0/). 